\title{
Head and Neck Pain in Patients Presenting with Acute Aortic Dissection
}

\author{
Stephen Philip, MD, MS ${ }^{1}$ Emil Missov, MD, PhD ${ }^{2}$ Dan Gilon, MD 3 Stuart Hutchison, MD 4
}

Ali Khoynezhad, MD, PhD ${ }^{5}$ Arturo Evangelista, $\mathrm{MD}^{6}$ Mark Bonaca, MD, MPH ${ }^{7}$ Lori Conklin, $\mathrm{MD}^{8}$

Jehangir Appoo, MD ${ }^{4}$ Marco Di Eusanio, MD, PhD ${ }^{9}$ Alan Braverman, MD ${ }^{10}$ Alberto Forteza, $\mathrm{MD}^{11}$

Daniel Montgomery, MS ${ }^{1}$ Christoph Nienaber, MD, PhD ${ }^{12}$ Eric Isselbacher, MD ${ }^{13}$ Kim Eagle, MD ${ }^{1}$

\footnotetext{
${ }^{1}$ Department of Internal Medicine, University of Michigan Health System, Ann Arbor, Michigan

${ }^{2}$ Department of Internal Medicine, University of Minnesota Physicians Heart Practice, Minneapolis, Minnesota

${ }^{3}$ Department of Non-invasive Cardiology, Hadassah Hebrew

University Medical Center, Jerusalem, Israel

${ }^{4}$ Libin Cardiovascular Institute, University of Calgary Medical Centre, Calgary, Canada

${ }^{5}$ Department of Cardiovascular Surgery, Long Beach Medical Center, Los Angeles, California

${ }^{6}$ Department of Cardiology, Hospital General Universitari Vall D'hebron, Barcelona, Spain

${ }^{7}$ Department of Cardiovascular Medicine, Brigham \& Women's Hospital, Boston, Massachusetts

${ }^{8}$ Department of Anesthesiology, University of Virginia Health System, Charlottesville, Virginia
}

\author{
Address for correspondence Stephen Philip, MD, MS, Department of \\ Internal Medicine, University of Michigan Health System, 24 Frank \\ Lloyd Wright Drive, Lobby A/3201, Ann Arbor, MI 48106 \\ (e-mail: Stephen.philip@phhs.org). \\ ${ }^{9}$ Department of Cardiovascular Surgery, Ospedali Riuniti Ancona, \\ Ancona, Italy \\ 10 Deparment of Cardiology, Washington University, School of \\ Medicine, St. Louis, Missouri \\ ${ }^{11}$ Department of Cardiac Surgery, Hospital Universitario Puerta De \\ Hierro, Madrid, Spain \\ ${ }^{12}$ Cardiology and Aortic Centre, The Royal Brompton \& Harefield Nhs \\ Trust, London, United Kingdom \\ 13 Thoracic Aortic Center, Massachusetts General Hospital, Boston, \\ Massachusetts
}

\begin{abstract}
Keywords

- Head Pain

- neck pain

- aortic dissection

Background Head and neck pain is an atypical presentation of acute aortic dissection. Classic teaching associates this pain with proximal dissections, but this has not been extensively studied.

Methods Patients enrolled in the International Registry of Acute Aortic Dissection from January 1996 to March 2015 were included in this study. We analyzed the demographics, presentation, treatment, and outcomes of Type A aortic dissection patients presenting with head and neck pain $(n=812,25.8 \%)$ and compared it with those without these symptoms ( $n=2,341,74.2 \%$ ).

Results Patients with head and neck pain were more likely to be white, female, with a family history of aortic disease. Patients with head and neck pain had higher percentages of back pain $(43.3 \%$ vs. $37.5 \%, p=0.005)$ and chest pain $(87.6 \%$ vs. $79.3 \%, p<0.001)$. On imaging, a higher percentage of those with head and neck pain had arch vessel involvement $(44.3 \%$ vs. $38 \%, p=0.010)$ and intramural hematoma ( $11.7 \%$ vs. $8.1 \%, p=0.003)$. Surgical management was more common in patients with head and neck pain $(89.8 \%$ vs. $85.2 \%$, $p=0.001)$. Regarding outcomes, patients with head and neck pain had significantly higher rates of stroke than those without head and neck pain (13\% vs. $9.9 \%, p=0.016)$; however, overall mortality was lower for those with head and neck pain ( $19.5 \%$ vs. $23 \%, p=0.038)$.
\end{abstract}

received

July 19, 2017

accepted after revision

November 5, 2018
DOI https://doi.org/

10.1055/s-0039-18388. ISSN 2325-4637.
Copyright $\odot 2018$ by Thieme Medical Publishers, Inc., 333 Seventh Avenue, New York, NY 10001, USA. Tel: +1(212) 584-4662.
License terms

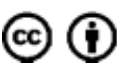


Those with head and neck pain only had higher overall mortality compared to those with head and neck pain with chest or back pain $(34.6 \%$ vs. $19.9 \%, p=0.013)$. A logistic regression of mortality revealed that preoperative hypotension and age $>65$ years were significantly associated with increased mortality.

Conclusion Presence of head and neck pain in Type A dissection is associated with more arch involvement, intramural hematoma, and stroke. When isolating those with head and neck pain only, there appear to be a higher rate of comorbidity burden and higher overall mortality.

\section{Introduction}

A 53-year-old Caucasian man was admitted to the hospital because of intense frontal headache and neck pain. In the past, he suffered from occasional migraine with aura, with predominant parietotemporal and occipital headache. The present episode started 36 hours before admission and was ushered in with a stabbing anterior chest pain lasting 10 minutes. A few minutes after the onset of chest pain, severe bifrontal headache evolved within 2 minutes, followed by additional neck pain. Moreover, the patient complained of nausea, dizziness, and flickering eyes. The headache persisted despite analgesics. Computed tomography scan showed no subarachnoid hemorrhage or aneurysm. Chest X-ray showed no abnormalities. However, transthoracic echocardiography showed a widened ascending aorta (54 mm) with an intimal flap and a severely regurgitant tricuspid aortic valve. ${ }^{1}$

Acute aortic dissection is a highly lethal condition, which has an estimated incidence of 2.9 per 100,000 in western Hungary to 3.5 per 100,000 person-years in Olmsted County, Minnesota. ${ }^{2,3}$ Though this condition is rare compared to myocardial infarction that has an incidence of 208 cases per 100,000 person-years, aortic dissection is still the most common life-threatening disorder affecting the aorta. ${ }^{4-6}$ This acute syndrome is rapidly fatal if undetected with a $20 \%$ prehospital lethality rate and up to $30 \%$ in-hospital mortality. ${ }^{7-9}$ The mortality reaches 1 to $3 \%$ per hour in the first 48 hours and without treatment, more than $75 \%$ of patients with a Type A dissection will die in 2 weeks. ${ }^{10}$ One of the difficulties with aortic dissection is the myriad ways in which it can present. Work done by the International Registry of Acute Aortic Dissection (IRAD) has shown that though many patients present with sudden severe chest pain, pulse deficits, and pain radiation, 10 to $15 \%$ of patients do not present with pain and a subset of other patients present with nonclassic symptoms such as neurologic deficits and syncope. ${ }^{4,8,11}$

These atypically presenting patients have a potential for delayed diagnosis, treatment, and worse outcomes compared with classically presenting patients. One of these atypical presentation symptoms is head and neck pain. Clinical teaching states that proximal dissections are more often associated with head and neck pain and neurologic symptoms due to arch involvement; however, there are little data in the published literature to support this claim. ${ }^{12}$ We sought to analyze the truth of this clinical anecdote while also looking at the demographics, presentation, treatment, and outcomes for acute Type A dissection patients with head and neck pain.

\section{Materials and Methods}

The patient's information regarding acute aortic dissection was collected from 43 centers in North America, Europe, Asia, and Australia on patients who presented between January 1996 and March 2015. These patients were identified via hospital discharge diagnosis records and the imaging databases of surgical and echocardiography laboratories. A 290-question survey, which included questions on demographics, history, physical findings, management, imaging, and outcomes, was then filled out. These data were then entered into an online database and reviewed by the IRAD coordinating center at the University of Michigan for face validity and completeness. ${ }^{4}$

The 3,027 acute Type A dissection patients were first separated into two cohorts: those with head and neck pain (791 patients) and those without head and neck pain (2,236 patients) for our main analysis. These groups were then further analyzed regarding demographic characteristics, presentation signs and symptoms, treatment types, and outcomes. Given our results, we performed a subgroup study in patients with head and neck pain, separating that group into those who had chest and back pain versus those without chest and back pain (therefore only head and neck pain). We also performed a logistic regression of mortality in this subset controlling for head and neck pain status, preoperative hypotension, age $>65$ years, site of intimal tear, and signs of intramural hematoma.

Categorical variables were analyzed using Pearson's chisquare analysis. Continuous variables without skewed means were analyzed using two-sided $t$-tests. Skewed continuous variables were analyzed using the Whitney-Mann $U$ asymptotic test. Logistic regressions models were analyzed using Hosmer-Lemeshow tests. Wald chi-square tests were used to find significance of the predictors.

\section{Results}

Our main analysis found several differences in the demographics between patients with head and neck pain versus those without head and neck pain as seen in -Table 1. There 
Table 1 Comparison of baseline demographic risk factors in patients with head and neck pain compared with those without head and neck pain

\begin{tabular}{|c|c|c|c|}
\hline Demographics & $\begin{array}{l}\text { Head and } \\
\text { neck } \\
\text { pain group }\end{array}$ & $\begin{array}{l}\text { No head } \\
\text { and neck } \\
\text { pain group }\end{array}$ & $p$-Value \\
\hline $\begin{array}{l}\text { Age (overall } \\
\text { mean) }\end{array}$ & 61.49 & 61.45 & 0.939 \\
\hline$<40 \mathrm{y}$ & 8.6 & 7.4 & 0.27 \\
\hline$>70 y$ & 30 & 30.4 & 0.831 \\
\hline Female sex & 39.8 & 31.3 & $<0.001$ \\
\hline White & 90.2 & 84 & $<0.001$ \\
\hline $\begin{array}{l}\text { African } \\
\text { American }\end{array}$ & 4.9 & 8.1 & 0.004 \\
\hline Asian & 2.3 & 5.3 & 0.001 \\
\hline $\begin{array}{l}\text { Family history of } \\
\text { aortic disease }\end{array}$ & 14.5 & 8.8 & 0.002 \\
\hline \multicolumn{4}{|l|}{ Risk factors: } \\
\hline $\begin{array}{l}\text { Marfan's } \\
\text { syndrome }\end{array}$ & 4.6 & 3.7 & 0.281 \\
\hline Smoking & 53.7 & 51.9 & 0.549 \\
\hline Hypertension & 72.6 & 72.5 & 0.965 \\
\hline Atherosclerosis & 23.7 & 18.9 & 0.005 \\
\hline Cocaine usage & 1.5 & 1.9 & 0.534 \\
\hline $\begin{array}{l}\text { Bicuspid aortic } \\
\text { valve }\end{array}$ & 5.3 & 3.9 & 0.13 \\
\hline Diabetes & 8.8 & 7.2 & 0.134 \\
\hline \multicolumn{4}{|l|}{ Prior surgery: } \\
\hline $\begin{array}{l}\text { Coronary } \\
\text { artery bypass } \\
\text { grafting }\end{array}$ & 3.5 & 5.3 & 0.053 \\
\hline $\begin{array}{l}\text { Aortic valve } \\
\text { replacement }\end{array}$ & 3.1 & 4.8 & 0.061 \\
\hline $\begin{array}{l}\text { Aortic } \\
\text { aneurysm/ } \\
\text { dissection } \\
\text { repair }\end{array}$ & 7 & 6.1 & 0.407 \\
\hline
\end{tabular}

Note: Bold values indicate significance at $p<0.05$.

were significantly more females with head and neck pain compared with those without $(39.8 \%$ vs. $31.3 \% p<0.001)$. There were significantly more white patients with head and neck pain (90.2\%) compared with those without $(84 \%$, $p<0.001)$. There were fewer African American patients with head and neck pain ( $4.9 \%$ vs. $8.1 \% p=0.004)$ and fewer Asian patients with head and neck pain (2.3\% vs. $5.3 \%$ $p=0.001)$. Finally, atherosclerosis and a family history of aortic disease were found more often in those with head and neck pain than those without $(23.7 \%$ vs. $18.9 \% p=0.005$, and $14.5 \%$ vs. $8.8 \% p=0.002$, respectively).

Regarding presentation symptoms (-Table 2 ), there appeared to be no significant difference in time from symptom onset to diagnosis or treatment between the two groups. There were interesting patterns in the quality of pain, however. Those with head and neck pain described significantly more sharp pain ( $49.6 \%$ vs. $43.6 \% p=0.024$ ), pressure-type pain (50.4\% vs. $38 \%$ $p<0.001)$, abrupt onset of pain (89.8\% vs. $78.5 \% p<0.001)$, back pain ( $43.3 \%$ vs. $37.5 \% p=0.005)$, chest pain $(87.6 \%$ vs. $79.3 \%$ $p<0.001)$, and migrating pain $(20.1 \%$ vs. $11 \% p<0.001)$. Patients with head and neck pain also tended to present with cardiovascular accident (CVA) more often ( $7 \%$ vs. $4.6 \% p=0.01$ ), arch vessel involvement ( $44.3 \%$ vs $38 \% p=0.01$ ), and intramural hematoma ( $11.7 \%$ vs. $8.1 \% p=0.003)$. However, patients with head and neck pain had significantly lower rates of congestive heart failure (CHF) $(4.8 \%$ vs. $7 \% p=0.03)$ and shock and tamponade ( $8.3 \%$ vs. $11.1 \% p=0.03$ ).

When treating patients in cohort 1 , those with head and neck pain were more likely to receive surgical treatment ( $89.8 \%$ vs. $85.2 \% p=0.001$ ) and correspondingly less likely to undergo medical treatment alone (7.8\% vs. $11.4 \% p=0.005)$. Significantly more patients with head and neck pain had partial arch replacement compared with those without head and neck pain ( $47.3 \%$ vs. $41.8 \% p=0.017$ ) (-Table 3 ).

While still in the hospital, patients with head and neck pain had higher rates of CVA as a complication (13\% vs. $9.9 \%$ $p=0.016$ ). Regarding overall outcomes (-Table 4), mortality among patients with head and neck was $19.5 \%$ compared with $23 \%$ in those without head and neck pain $(p=0.038)$. Surgical mortality was slightly lower among patients with head and neck (14.8\% and $18.8 \% p=0.017)$. Conversely, those patients treated medically showed higher mortality rates among patients with head and neck pain compared with those without $(67.7 \%$ vs. $51.6 \% p=0.022)$.

In our subgroup analysis of patients with head and neck pain only versus those who had head and neck pain with chest or back, we found that those with head and neck pain only were significantly older (66.4 vs. $61.1 p=0.001$ ). Furthermore, those with head and neck pain only had higher rates of diabetes ( $19.6 \%$ vs. $7.4 \% p=0.003)$, atherosclerosis (39.2\% vs. $24.1 \% p=0.018$ ), and previous coronary bypass surgery ( $12 \%$ vs. $1.9 \% p<0.001$ ) compared with those who also had chest or back pain (- Table $\mathbf{5}$ ).

At presentation, there were higher rates of coma and altered mental status (32.7\% vs. 9.1\% $p<0.001$ ), syncope (32.7\% vs. $14.4 \% p=0.001)$, and CVA ( $18.4 \%$ vs. $6.6 \% p=0.003)$ in the head and neck pain only group as seen in - Table $\mathbf{6}$. However, we found no difference in time to presentation or time to diagnosis between the two groups in cohort 2. Furthermore, there was no difference found in management type or extent of surgery between the two groups ( - Table 7 ).

Regarding outcomes, there was a significantly higher percentage of patients with head and neck pain only who had cardiac tamponade while in the hospital (30\% vs. $16.6 \%$ $p=0.018$ ). Regarding mortality rates, patients with head and neck pain only had higher overall mortality (34.6\% vs. $19.9 \% p=0.013)$ and higher surgical mortality (29.5\% vs. $15.3 \% p=0.014$ ) ( - Table 8). A logistic regression of mortality was conducted with predictive variables of head and pain, preoperative hypotension, presence of ascending intimal tear, or intramural hematomas, which found that head and neck pain status was not associated with higher mortality after controlling for the other factors $(p=0.36)$ (-Tables 9-11). 
Head and Neck Pain in Aortic Dissection Philip et al. 133

Table 2 Comparison of presenting symptoms in patients with head and neck pain compared with those without head and neck pain

\begin{tabular}{|c|c|c|c|}
\hline Variables & $\begin{array}{l}\text { Head/ } \\
\text { neck pain } \\
\text { group }\end{array}$ & $\begin{array}{l}\text { No head/ } \\
\text { neck pain } \\
\text { group }\end{array}$ & $p$-Value \\
\hline $\begin{array}{l}\text { Hours from } \\
\text { symptom onset to } \\
\text { presentation at } \\
\text { initial hospital }\end{array}$ & $0.75-3.33$ & $0.833-3.5$ & 0.189 \\
\hline $\begin{array}{l}\text { Presenting within } \\
6 \mathrm{~h} \text { of symptom } \\
\text { onset }\end{array}$ & 87.4 & 84 & 0.076 \\
\hline $\begin{array}{l}\text { Hours from } \\
\text { symptom onset to } \\
\text { presentation at } \\
\text { initial hospital }\end{array}$ & $0.75-3.33$ & $0.833-3.5$ & 0.189 \\
\hline $\begin{array}{l}\text { Hours from } \\
\text { symptom onset to } \\
\text { diagnosis (avg) }\end{array}$ & $2.87-12.75$ & $2.66-12.19$ & 0.534 \\
\hline \multicolumn{4}{|l|}{$\begin{array}{l}\text { Hours from } \\
\text { symptom onset to } \\
\text { diagnosis: }\end{array}$} \\
\hline $0-4 \mathrm{~h}$ & 40.6 & 41.9 & \\
\hline $4-24 \mathrm{~h}$ & 45.2 & 43.1 & \\
\hline $24 \mathrm{~h}$ & 14.2 & 15.1 & \\
\hline \multicolumn{4}{|l|}{ Quality of pain: } \\
\hline Tearing/ripping & 29.9 & 30.2 & 0.926 \\
\hline Sharp & 49.6 & 43.6 & 0.024 \\
\hline Pressure & 50.4 & 38 & $<0.001$ \\
\hline Burning & 13.8 & 12.6 & 0.534 \\
\hline $\begin{array}{l}\text { Abrupt onset of } \\
\text { pain }\end{array}$ & 89.8 & 78.5 & $<0.001$ \\
\hline Back pain & 43.3 & 37.5 & 0.005 \\
\hline Chest pain & 87.6 & 79.3 & $<0.001$ \\
\hline Migrating pain & 20.1 & 11 & $<0.001$ \\
\hline $\begin{array}{l}\text { Coma/altered } \\
\text { consciousness }\end{array}$ & 10 & 10.7 & 0.598 \\
\hline Syncope & 16.7 & 16.5 & 0.927 \\
\hline $\begin{array}{l}\text { Cardiovascular } \\
\text { accident }\end{array}$ & 7 & 4.6 & 0.01 \\
\hline $\begin{array}{l}\text { Congestive heart } \\
\text { failure }\end{array}$ & 4.8 & 7 & 0.03 \\
\hline $\begin{array}{l}\text { Hypotension/ } \\
\text { shock/ } \\
\text { tamponade }\end{array}$ & 24.9 & 27.6 & 0.168 \\
\hline $\begin{array}{l}\text { Shock/ } \\
\text { tamponade }\end{array}$ & 8.3 & 11.1 & 0.03 \\
\hline Shock & 5.7 & 7.8 & 0.07 \\
\hline Tamponade & 2.5 & 3.4 & 0.266 \\
\hline $\begin{array}{l}\text { Murmur of } \\
\text { aortic } \\
\text { insufficiency }\end{array}$ & 35.8 & 33.7 & 0.337 \\
\hline Any pulse deficit & 33 & 34.8 & 0.451 \\
\hline \multicolumn{4}{|l|}{$\begin{array}{l}\text { Diagnostic } \\
\text { imaging findings: }\end{array}$} \\
\hline $\begin{array}{l}\text { Arch vessel } \\
\text { involvement }\end{array}$ & 44.3 & 38 & 0.01 \\
\hline
\end{tabular}

(Continued)
Table 2 (Continued)

\begin{tabular}{|c|c|c|c|}
\hline Variables & $\begin{array}{l}\text { Head/ } \\
\text { neck pain } \\
\text { group }\end{array}$ & $\begin{array}{l}\text { No head/ } \\
\text { neck pain } \\
\text { group }\end{array}$ & $p$-Value \\
\hline $\begin{array}{l}\text { Intramural } \\
\text { hematoma (def) }\end{array}$ & 11.7 & 8.1 & 0.003 \\
\hline $\begin{array}{l}\text { Periaortic } \\
\text { hematoma }\end{array}$ & 21 & 19.6 & 0.463 \\
\hline $\begin{array}{l}\text { False lumen } \\
\text { thrombosis, } \\
\text { complete }\end{array}$ & 9.3 & 9 & 0.855 \\
\hline $\begin{array}{l}\text { False lumen } \\
\text { thrombosis, } \\
\text { partial }\end{array}$ & 18.9 & 20.3 & 0.517 \\
\hline $\begin{array}{l}\text { Coronary artery } \\
\text { compromise }\end{array}$ & 12.9 & 12.9 & 0.978 \\
\hline $\begin{array}{l}\text { Pericardial } \\
\text { effusion }\end{array}$ & 41.9 & 41.9 & 0.993 \\
\hline \multicolumn{4}{|l|}{$\begin{array}{l}\text { Chest X-ray } \\
\text { findings: }\end{array}$} \\
\hline$\%$ abnormal & 72.8 & 73.3 & 0.82 \\
\hline $\begin{array}{l}\text { Wide } \\
\text { mediastinum }\end{array}$ & 53 & 52.7 & 0.931 \\
\hline $\begin{array}{l}\text { Abnormal } \\
\text { aortic contour }\end{array}$ & 41.6 & 41.8 & 0.922 \\
\hline $\begin{array}{l}\text { Abnormal } \\
\text { cardiac contour }\end{array}$ & 22.6 & 24.8 & 0.362 \\
\hline $\begin{array}{l}\text { Displacement/ } \\
\text { calcification of } \\
\text { the aorta }\end{array}$ & 5.4 & 6.5 & 0.423 \\
\hline Pleural effusion & 9.3 & 12.8 & 0.051 \\
\hline
\end{tabular}

Note: Bold values indicate significance at $p<0.05$.

Table 3 Treatment modalities for the head and neck pain and no head and neck pain

\begin{tabular}{|l|l|l|l|}
\hline Variables & $\begin{array}{l}\text { Head/ } \\
\text { neck pain } \\
\text { group }\end{array}$ & $\begin{array}{l}\text { No head/ } \\
\text { neck pain } \\
\text { group }\end{array}$ & -Value \\
\hline Type of management & & & \\
\hline Type A surgical & 89.8 & 85.2 & 0.001 \\
\hline Type A medical & 7.8 & 11.4 & 0.005 \\
\hline Endovascular & 1.3 & 1.8 & 0.284 \\
\hline Surgery & 15.5 & 15.4 & 0.938 \\
\hline $\begin{array}{l}\text { Surgery after 24 h } \\
\text { Hours from symptom } \\
\text { onset to surgery }\end{array}$ & $6-21$ & $6-21$ & 0.244 \\
\hline Root replacement & 34.7 & 37.9 & 0.171 \\
\hline $\begin{array}{l}\text { Ascending aortic } \\
\text { replacement }\end{array}$ & 95.1 & 93.7 & 0.202 \\
\hline $\begin{array}{l}\text { Complete arch } \\
\text { replacement }\end{array}$ & 16.4 & 17.1 & 0.704 \\
\hline $\begin{array}{l}\text { Partial arch } \\
\text { replacement }\end{array}$ & 57.3 & 56.8 & \\
\hline $\begin{array}{l}\text { Initial management } \\
\text { of } \beta \text {-blockers }\end{array}$ & 56.5 & & \\
\hline
\end{tabular}

Note: Bold values indicate significance at $p<0.05$. 
134 Head and Neck Pain in Aortic Dissection Philip et al.

Table 4 Hospital complications and overall outcomes for patients with head and neck pain compared with those without head and neck pain

\begin{tabular}{|l|l|l|l|}
\hline Variables & $\begin{array}{l}\text { Head/ } \\
\text { neck pain } \\
\text { group }\end{array}$ & $\begin{array}{l}\text { No head/ } \\
\text { neck pain } \\
\text { group }\end{array}$ & $p$-Value \\
\hline In-hospital complications: & & & \\
\hline New neurologic deficit & 26.5 & 24.8 & 0.343 \\
\hline Cerebral vascular injury & 13 & 9.9 & 0.016 \\
\hline Transient neurodeficit & 67.9 & 60.1 & 0.085 \\
\hline Coma & 4.5 & 5.5 & 0.314 \\
\hline Myocardial ischemia & 85.1 & 88.2 & 0.063 \\
\hline Hypotension & 29.4 & 29.3 & 0.939 \\
\hline Cardiac tamponade & 18.2 & 18.6 & 0.799 \\
\hline Mortality: & & & \\
\hline Type A overall & 19.5 & 23 & 0.038 \\
\hline Type A surgical mortality & 14.8 & 18.8 & 0.017 \\
\hline Type A medical mortality & 67.7 & 51.6 & 0.022 \\
\hline Cause of mortality: & & & \\
\hline Neurologic & 10.4 & 8.2 & 0.387 \\
\hline Tamponade & 4.5 & 6.8 & 0.312 \\
\hline Visceral Ischemia & 8.4 & 8.5 & 0.968 \\
\hline Bleeding & 5.2 & 2.5 & 0.095 \\
\hline multiorgan failure & 9.7 & 9.7 & 0.991 \\
\hline Cardiac & 7.8 & 9.1 & 0.609 \\
\hline Rupture & 18.2 & 18.3 & 0.984 \\
\hline Unknown & 1.9 & 4.1 & 0.557 \\
\hline & & & \\
\hline
\end{tabular}

Note: Bold values indicate significance at $p<0.05$.

\section{Discussion}

The acute and lethal nature of acute aortic dissection creates strong impetus for discovering risk factors, symptoms, and other patterns that may speed its diagnosis and decrease its mortality. Complicating this effort are the multiple presenting patterns that occur clinically. ${ }^{9,13-16}$ Head and neck pain is one of these aberrant presentation patterns, which is present in $26.1 \%$ of all Type A patients in our database to date.

The pathophysiology of this pain location is not well defined in the literature. Whereas classic angina pectoris is thought to be caused by stimulation of sympathetic afferent nerves around the heart, several studies suggest that the afferent pathway of the vagus nerve may be a cause of cardiac-related head and neck pain. Stimulation of vagal afferents stimulates nerve endings in $\mathrm{C} 1-\mathrm{C} 3$, which corresponds to the receptive field for the neck, jaw, upper arm, and ear. ${ }^{17-19}$

Another possible mechanism of head pain might be partially explained by our findings that there were significantly more patients with arch vessel involvement and CVA in the head and neck cohort. Because the anterior and posterior circulations of the brain derive from the carotids and the vertebral arteries, respectively, which ultimately
Table 5 Comparison of baseline demographic risk factors in patients with head and neck pain only compared with those with head and neck pain with chest or back pain

\begin{tabular}{|l|l|l|l|}
\hline Demographics & $\begin{array}{l}\text { Head/neck } \\
\text { pain only } \\
\text { group }\end{array}$ & $\begin{array}{l}\text { Head/ } \\
\text { neck pain } \\
\text { chest/ } \\
\text { back pain } \\
\text { group }\end{array}$ & $p$-Value \\
\hline Age (overall mean) & $66.4 \pm 10.6$ & $61.1 \pm 14.4$ & 0.001 \\
\hline$<40$ y & $1(1.9 \%)$ & $45(8.3 \%)$ & 0.167 \\
\hline$>70$ y & $19(36.5 \%)$ & $160(29.5 \%)$ & 0.292 \\
\hline Female sex & $14(26.9 \%)$ & $207(38.2 \%)$ & 0.108 \\
\hline White & $45(91.8 \%)$ & $481(93.6 \%)$ & 0.552 \\
\hline African American & $1(2 \%)$ & $16(3.1 \%)$ & 1.000 \\
\hline Asian & $1(2 \%)$ & $9(1.8 \%)$ & 0.601 \\
\hline $\begin{array}{l}\text { Family history of } \\
\text { aortic disease }\end{array}$ & $0(0 \%)$ & $30(14.2 \%)$ & 0.084 \\
\hline Risk factors: & & & $0.04 \%$ \\
\hline Marfan's syndrome & $1(2 \%)$ & $25(4.7 \%)$ & 0.717 \\
\hline Smoking (current) & $5(26.3 \%)$ & $68(33 \%)$ & 0.551 \\
\hline Hypertension & $39(78 \%)$ & $378(71.5 \%)$ & 0.324 \\
\hline Atherosclerosis & $20(39.2 \%)$ & $126(24.1 \%)$ & 0.018 \\
\hline Cocaine usage & $0(0 \%)$ & $8(1.6 \%)$ & 1.000 \\
\hline $\begin{array}{l}\text { Bicuspid aortic } \\
\text { valve }\end{array}$ & $2(4.8 \%)$ & $29(6.1 \%)$ & 1.000 \\
\hline Diabetes & $10(19.6 \%)$ & $39(7.4 \%)$ & 0.003 \\
\hline Prior surgery: & $6(12 \%)$ & $10(1.9 \%)$ & $<0.001$ \\
\hline $\begin{array}{l}\text { Coronary artery } \\
\text { bypass grafting }\end{array}$ & $1(2 \%)$ & $13(2.5 \%)$ & 1.000 \\
\hline $\begin{array}{l}\text { Aortic valve } \\
\text { replacement }\end{array}$ & $4(8.2 \%)$ & $36(7 \%)$ & 0.769 \\
\hline $\begin{array}{l}\text { Aortic aneurysm/ } \\
\text { dissection repair }\end{array}$ & & & \\
\hline
\end{tabular}

Note: Bold values indicate significance at $p<0.05$.

obtain blood flow from the aorta, arch vessel involvement has the potential to directly alter flow to the brain. Thus, this would represent a primary cause of the pain rather than referred pain from the heart. Studies have shown that patients with carotid or vertebral dissection can present with headache and neck pain. ${ }^{20,21}$

Regarding the higher proportion of head and neck pain found in women in our first analysis (-Table 1), it has been shown in two IRAD analyses that women on average present differently than men do with aortic dissection. Women were found to present more frequently with coma and/or altered mental status compared with men. ${ }^{13,22}$ Our current data suggest that one reason for higher rates of head and neck pain among women might be more frequent CVA. A 2004 IRAD paper found that $7.9 \%$ of women with acute aortic dissection presented with CVA compared with 5.2\% men, though this difference was not significant. ${ }^{13}$ When analyzing the subgroups in cohort 2, this gender preponderance of head and neck pain in women did not remain. This suggests that though women are more likely to experience head and 
Table 6 Comparison of presenting symptoms in patients with head and neck pain only compared with those with head and neck pain with chest or back pain

\begin{tabular}{|c|c|c|c|}
\hline Variables & $\begin{array}{l}\text { Head/neck pain } \\
\text { only group }\end{array}$ & $\begin{array}{l}\text { Head/neck pain }+ \text { chest/back } \\
\text { pain group }\end{array}$ & $p$-Value \\
\hline Presenting within $6 \mathrm{~h}$ of symptom onset & $28(90.3 \%)$ & $324(86.9 \%)$ & 0.782 \\
\hline $\begin{array}{l}\text { Hours from symptom onset to } \\
\text { presentation at initial hospital }\end{array}$ & $1.25(0.85-4.42)$ & $1.25(0.75-3.21)$ & 0.600 \\
\hline Hours from symptom onset to diagnosis (avg) & $5.62(3.13-10.13)$ & $5.17(2.88-14.00)$ & 0.889 \\
\hline Hours from symptom onset to diagnosis: & & & 0.770 \\
\hline $0-4 \mathrm{~h}$ & $10(34.5 \%)$ & $135(40.1 \%)$ & \\
\hline $4-24 \mathrm{~h}$ & $15(51.7 \%)$ & $151(44.8 \%)$ & \\
\hline $24 \mathrm{~h}$ & $4(13.8 \%)$ & $51(15.1 \%)$ & \\
\hline \multicolumn{4}{|l|}{ Quality of pain: } \\
\hline Tearing/ripping & $3(12.5 \%)$ & $116(35.3 \%)$ & 0.024 \\
\hline Sharp & $11(44 \%)$ & $169(50.8 \%)$ & 0.515 \\
\hline Pressure & $11(39.3 \%)$ & $172(55.3 \%)$ & 0.103 \\
\hline Burning & $5(20.8 \%)$ & $42(15.3 \%)$ & 0.478 \\
\hline Abrupt onset of pain & $43(84.3 \%)$ & $477(90.2 \%)$ & 0.19 \\
\hline Back pain & $0(0 \%)$ & $256(47.2 \%)$ & $<0.001$ \\
\hline Chest pain & $0(0 \%)$ & $521(96.1 \%)$ & $<0.001$ \\
\hline Migrating pain & $2(4 \%)$ & $112(21.5 \%)$ & 0.001 \\
\hline Coma/altered consciousness & $16(32.7 \%)$ & $47(9.1 \%)$ & $<0.001$ \\
\hline Syncope & $17(32.7 \%)$ & $77(14.4 \%)$ & 0.001 \\
\hline Cardiovascular accident & $9(18.4 \%)$ & $34(6.6 \%)$ & 0.003 \\
\hline Congestive heart failure & $3(6.4 \%)$ & $23(4.5 \%)$ & 0.471 \\
\hline Hypotension/shock/tamponade & $14(28.6 \%)$ & $126(24.3 \%)$ & 0.505 \\
\hline Shock/tamponade & $2(4.1 \%)$ & $43(8.3 \%)$ & 0.412 \\
\hline Shock & $1(2 \%)$ & $31(6 \%)$ & 0.510 \\
\hline Tamponade & $1(2 \%)$ & $12(2.3 \%)$ & 1.000 \\
\hline Murmur of aortic insufficiency & $17(36.2 \%)$ & $178(38.5 \%)$ & 0.751 \\
\hline Any pulse deficit & $11(33.3 \%)$ & $111(27.8 \%)$ & 0.499 \\
\hline \multicolumn{4}{|l|}{ Diagnostic imaging findings: } \\
\hline Arch vessel involvement & $23(56.1 \%)$ & $169(41.8 \%)$ & 0.079 \\
\hline Intramural hematoma (def) & $5(9.6 \%)$ & $62(11.6 \%)$ & 0.663 \\
\hline Periaortic hematoma & $7(14.9 \%)$ & $103(23.8 \%)$ & 0.168 \\
\hline False lumen thrombosis, complete & $0(0 \%)$ & $34(10.1 \%)$ & 0.093 \\
\hline False lumen thrombosis, partial & $6(21.4 \%)$ & $62(18.4 \%)$ & 0.692 \\
\hline Coronary artery compromise & $3(7 \%)$ & $52(13.6 \%)$ & 0.336 \\
\hline Pericardial effusion & $23(45.1 \%)$ & $203(42.3 \%)$ & 0.700 \\
\hline \multicolumn{4}{|l|}{ Chest X-ray findings: } \\
\hline$\%$ abnormal & $30(78.9 \%)$ & $301(75.3 \%)$ & 0.612 \\
\hline Wide mediastinum & $18(48.6 \%)$ & $199(52.5 \%)$ & 0.654 \\
\hline Abnormal aortic contour & $15(40.5 \%)$ & $153(41.2 \%)$ & 0.934 \\
\hline Abnormal cardiac contour & $9(24.3 \%)$ & $76(20.7 \%)$ & 0.601 \\
\hline Displacement/calcification of the aorta & $4(10.8 \%)$ & $20(5.4 \%)$ & 0.258 \\
\hline Pleural effusion & $1(2.7 \%)$ & $35(9.4 \%)$ & 0.231 \\
\hline
\end{tabular}

Note: Bold values indicate significance at $p<0.05$. 
Table 7 Treatment modality used for those with head and neck pain only compared with those with head and neck pain and chest or back pain

\begin{tabular}{|l|l|l|l|}
\hline Variables & Head/neck pain only group & $\begin{array}{l}\text { Head/neck pain }+ \text { chest/back } \\
\text { pain group }\end{array}$ & $p$-Value \\
\hline Type of management: & & & \\
\hline Type A surgical & $44(84.6 \%)$ & $491(90.6 \%)$ & 0.169 \\
\hline Type A medical & $7(13.5 \%)$ & $42(7.7 \%)$ & 0.153 \\
\hline Endovascular & 0 & $3(0.6 \%)$ & 1 \\
\hline Surgery: & & & \\
\hline Surgery after 24 h & $9(20 \%)$ & $79(16.2 \%)$ & $10.64(6.73-23.63)$ \\
\hline Hours from symptom onset to surgery & $11(7.75-25.17)$ & 1 & 0.51 \\
\hline Root replacement & $14(34.1 \%)$ & $443(94.5 \%)$ & 0.481 \\
\hline Ascending aortic replacement & $42(93.3 \%)$ & $64(14.4 \%)$ & 0.793 \\
\hline Complete arch replacement & $6(14 \%)$ & $20(46.4 \%)$ & 0.733 \\
\hline Partial arch replacement & $20(44.4 \%)$ & $268(53.5 \%)$ & 0.93 \\
\hline Initial management of $\beta$-blockers & $21(47.7 \%)$ & & 0.798 \\
\hline
\end{tabular}

Table 8 Hospital complications and overall outcomes for patients with head and neck pain only compared with those with head and neck pain with chest or back pain

\begin{tabular}{|c|c|c|c|}
\hline Variables & Head/neck pain only group & Head/neck pain + chest/back pain group & $p$-Value \\
\hline \multicolumn{4}{|l|}{ In-hospital complications: } \\
\hline New neurologic deficit & 19 (36.5\%) & $144(27.5 \%)$ & 0.167 \\
\hline Cerebral vascular injury & $14(26.9 \%)$ & $71(13.8 \%)$ & 0.011 \\
\hline \multicolumn{4}{|l|}{ Transient neurodeficit } \\
\hline Coma & $4(7.7 \%)$ & $24(4.7 \%)$ & 0.312 \\
\hline Myocardial ischemia & $4(8.3 \%)$ & $63(12.6 \%)$ & 0.494 \\
\hline Hypotension & $16(31.4 \%)$ & $163(31.5 \%)$ & 0.989 \\
\hline Cardiac tamponade & $15(30 \%)$ & $86(16.6 \%)$ & 0.018 \\
\hline \multicolumn{4}{|l|}{ Mortality: } \\
\hline Type A overall & $18(34.6 \%)$ & $108(19.9 \%)$ & 0.013 \\
\hline Type A surgical mortality & $13(29.5 \%)$ & $27(15.3 \%)$ & 0.014 \\
\hline Type A medical mortality & $5(71.4 \%)$ & $28(66.7 \%)$ & 1 \\
\hline \multicolumn{4}{|l|}{ Cause of mortality: } \\
\hline Neurologic & $3(16.7 \%)$ & $13(12 \%)$ & 0.701 \\
\hline Tamponade & 0 & $6(5.6 \%)$ & 0.593 \\
\hline Visceral ischemia & $3(16.7 \%)$ & $9(8.3 \%)$ & 0.377 \\
\hline Bleeding & $1(5.6 \%)$ & $6(5.6 \%)$ & 1 \\
\hline Multiorgan failure & $1(5.6 \%)$ & $6(5.6 \%)$ & 1 \\
\hline Cardiac & $0(5.6 \%)$ & $9(8.3 \%)$ & 1 \\
\hline Rupture & $1(5.6 \%)$ & $26(24.1 \%)$ & 0.118 \\
\hline Unknown & $6(33.3 \%)$ & $31(28.7 \%)$ & 0.69 \\
\hline
\end{tabular}

Note: Bold values indicate significance at $p<0.05$.

neck pain overall, those women who have head and neck pain are equally likely to present with chest pain and back pain or with head and neck pain only.

An unexpected finding in our first analysis was the higher rates of chest pain and back pain in the head and neck group along with higher rates of all of the various permutations of pain types such as tearing, sharp, and migrating (-Table 2). This may be because "worst-ever pain" in the chest, which radiates to the back, is still the predominant way that patients experience acute aortic dissection, it will remain the most prevalent presentation despite the presence of head and neck pain. ${ }^{16,23,24}$ On the other hand, a reason that the non-head and 
Table 9 Logistic regression model of mortality with independent variables of head and neck pain status, age $>65$ years, preoperative hypotension, ascending intimal tear, intramural hematoma

\begin{tabular}{|l|l|l|l|l|l|}
\hline Variables & $\beta$-Coefficient & $p$-Value & Risk ratio & $\begin{array}{l}\text { 95\% confidence } \\
\text { interval: lower }\end{array}$ & $\begin{array}{l}\text { 95\% confidence } \\
\text { interval: upper }\end{array}$ \\
\hline Head and neck and chest or back pain & -0.396 & 0.359 & 0.673 & 0.289 & 1.568 \\
\hline Age $>65$ y & 0.806 & $\mathbf{0 . 0 0 3}$ & 2.238 & 1.318 & 3.802 \\
\hline Preoperative hypotension & 1.395 & $\mathbf{0 . 0 0 0}$ & 4.037 & 2.348 & 6.942 \\
\hline Ascending intimal tear & -0.837 & $\mathbf{0 . 0 0 2}$ & 0.433 & 0.252 & 0.745 \\
\hline Intramural hematoma & -0.705 & 0.05 & 0.494 & 0.244 & 1.001 \\
\hline Constant & -1.277 & $\mathbf{0 . 0 0 4}$ & 0.279 & & \\
\hline
\end{tabular}

Note: Bold values indicate significance at $p<0.05$.

Table 10 Hosmer-Lemeshow test for model fit

\begin{tabular}{|l|l|l|}
\hline Chi-square & Degrees of freedom & Significance \\
\hline 10.495 & 8 & 0.232 \\
\hline
\end{tabular}

Note: Bold values indicate significance at $p<0.05$.

Table 11 Area under the curve for the logistic regression model

\begin{tabular}{|l|}
\hline Area under the curve \\
\hline 0.736 \\
\hline
\end{tabular}

neck group had fewer types of pain may be related to the fact that $15 \%$ of patients present with painless dissection, suggesting that there may be aortic dissection patients who are biologically predisposed to feel less pain. ${ }^{8,25}$ In fact, in our second analysis, those who experienced isolated head and neck pain were more likely to be older, have more atherosclerosis, and had a higher prevalence of diabetes, all of which were shown to be higher in patients who presented with painless cardiac syndromes. ${ }^{25-28}$ In addition, patients with head and neck pain had higher rates of syncope, coma/altered mental status, syncope, and CVA, which are neurologic phenomena, which may affect the ability to perceive pain, and which may explain why these patients did not report more types of pain. ${ }^{29}$

Despite the potential for delayed diagnosis, we found no delay to diagnosis or treatment in either cohort. Furthermore, in cohort 1, those with head or neck pain had lower overall mortality and lower surgical mortality. This was unexpected given the atypical presentation. However, given the fact that those with head and neck pain had a higher rate of chest pain and back pain than the group without head and neck pain, we wondered whether the presence of chest and back pain obscured the impact of having head and neck pain. Thus, we conducted a second analysis (cohort 2) with head and neck pain only versus those with head and neck pain with chest or back pain to see the effect of having only head and neck pain (without the influence of chest pain or back pain). We found in the second analysis that there was significantly higher overall and surgical mortality in the head and neck pain only group.
Reasons for the difference in mortality between cohorts 1 and 2 are not clear. Despite those in cohort 1 with head and neck pain having higher rates of the classic symptoms such as chest pain and back pain, we did not see any improvement in time to diagnosis in that group, which would explain their lower mortality. On the other hand, in cohort 2, those who experienced only head and neck pain were older, had higher rates of atherosclerosis, diabetes, and had more coronary artery bypass grafting operations, which represent several important risk factors for mortality. ${ }^{29-31}$ To analyze this further, we created a logistic regression model for mortality with head and neck pain status, age $>65$ years, preoperative hypotension, site of intimal tear and evidence of intramural hematoma as the dependent variables. Ultimately, when controlled for those variables, head and pain neck pain status was no longer significant associated with increased mortality. Given that age $>65$ and preoperative hypotension had significant, positive risk ratios in the model, this suggests that these two variables explained some of the increase in mortality.

In conclusion, we have shown that patients with head and neck pain have higher rates of proximal arch involvement and stroke, which adds credence to classic clinical teaching about the association of head and neck pain with arch involvement. Furthermore, patients with head and neck overall tend to have classic dissection symptoms and thus have no delay in diagnosis and also lower mortality compared with those without head and neck pain. However, in our subgroup analysis (cohort 2), we showed that those with isolated head and neck pain tend to have worse comorbidities, more neurologic symptoms on presentation, and worse overall and surgical mortality. This higher mortality may be partially explained by the older age and more preoperative hypotension in the head and neck pain only group. These patients, though a small fraction of our Type A dissection population, represent an area for added vigilance and improvement in our pursuit of better care of acute aortic dissection patients.

Our study has several limitations. IRAD is composed of patients in academic referral centers and may not represent the overall population of aortic dissection patients. In addition, patients with abnormal presentations may pass away prior to diagnosis or transfer to tertiary aortic centers and are thus underrepresented in our population. Furthermore, given our 
international scope, there is possible variation in treatment patterns, which may complicate outcomes measurements.

\section{Funding}

This research was generously supported by W.L. Gore \& Associates, Inc.; Medtronic; Varbedian Aortic Research Fund; The Hewlett Foundation; the Mardigian Foundation; UM Faculty Group Practice; Terumo; and Ann and Bob Aikens.

\section{Conflict of Interest}

The authors declare no conflict of interest related to this article.

\section{Acknowledgements}

None.

\section{References}

1 Mathys J, Lachat M, Herren T. Headache as a manifestation of a lifethreatening vascular disorder. Headache 2004;44(07):706-709

2 Mészáros I, Mórocz J, Szlávi J, et al. Epidemiology and clinicopathology of aortic dissection. Chest 2000;117(05):1271-1278

3 Clouse WD, Hallett JW Jr, Schaff HV, et al. Acute aortic dissection: population-based incidence compared with degenerative aortic aneurysm rupture. Mayo Clin Proc 2004;79(02):176-180

4 Hagan PG, Nienaber CA, Isselbacher EM, et al. The International Registry of Acute Aortic Dissection (IRAD): new insights into an old disease. JAMA 2000;283(07):897-903

5 Braverman AC. Acute aortic dissection: clinician update. Circulation 2010;122(02):184-188

6 Yeh RW, Sidney S, Chandra M, Sorel M, Selby JV, Go AS. Population trends in the incidence and outcomes of acute myocardial infarction. N Engl J Med 2010;362(23):2155-2165

7 Olsson C, Thelin S, Ståhle E, Ekbom A, Granath F. Thoracic aortic aneurysm and dissection: increasing prevalence and improved outcomes reported in a nationwide population-based study of more than 14,000 cases from 1987 to 2002 . Circulation 2006;114 (24):2611-2618

8 Elefteriades JA, Olin JW, Halperin JL. Diseases of the aorta. In: Fuster V, Walsh RA, Harrington RA. eds. Hurst's The Heart, 13th ed. New York, NY: McGraw-Hill; 201 :chap 106. http://accessmedicine.mhmedical.com/content.aspx?bookid=376\&Sectionid=40279845. Accessed March 17, 2016.

9 Harris KM, Strauss CE, Eagle KA, et al; International Registry of Acute Aortic Dissection (IRAD) Investigators. Correlates of delayed recognition and treatment of acute type A aortic dissection: the International Registry of Acute Aortic Dissection (IRAD). Circulation 2011;124(18):1911-1918

10 Woo KM, Schneider JI. High-risk chief complaints I: chest painthe big three. Emerg Med Clin North Am 2009;27(04):685-712, x

11 Golledge J, Eagle KA. Acute aortic dissection. Lancet 2008;372 (9632);55-66

12 Stöllberger C, Finsterer J, Fousek C, Waldenberger FR, Haumer H, Lorenz $\mathrm{W}$. Headache as the initial manifestation of acute aortic dissection type A. Cephalalgia 1998;18(08):583-584
13 Nienaber CA, Fattori R, Mehta RH, et al; International Registry of Acute Aortic Dissection. Gender-related differences in acute aortic dissection. Circulation 2004;109(24):3014-3021

14 Klompas M. Does this patient have an acute thoracic aortic dissection? JAMA 2002;287(17):2262-2272

15 Park SW, Hutchison S, Mehta RH, et al. Association of painless acute aortic dissection with increased mortality. Mayo Clin Proc 2004;79(10):1252-1257

16 Nienaber CA, Clough RE. Management of acute aortic dissection. Lancet 2015;385(9970):800-811

17 Foreman RD. Mechanisms of cardiac pain. Annu Rev Physiol 1999; 61:143-167Review

18 Myers DE. Vagus nerve pain referred to the craniofacial region. A case report and literature review with implications for referred cardiac pain. Br Dent J 2008;204(04):187-189

19 Chandler MJ, Zhang J, Qin C, Yuan Y, Foreman RD. Intrapericardiac injections of algogenic chemicals excite primate $\mathrm{C} 1-\mathrm{C} 2$ spinothalamic tract neurons. Am J Physiol Regul Integr Comp Physiol 2000; 279(02):R560-R568

20 Blum CA, Yaghi S. Cervical artery dissection: a review of the epidemiology, pathophysiology, treatment, and outcome. Arch Neurosci 2015;2(04):e26670

21 Grotta JC. Clinical practice. Carotid stenosis. N Engl J Med 2013; 369(12):1143-1150

22 Philip S, Pape L, Suzuki T, et al. Changes in gender-related differences in acute aortic dissection over time. J Am Coll Cardiol 2014;63(12):A2059

23 Pape LA, Awais M, Woznicki EM, et al. Presentation, diagnosis, and outcomes of acute aortic dissection: 17-year trends from the International Registry of Acute Aortic Dissection. J Am Coll Cardiol 2015;66(04):350-358

24 Thrumurthy SG, Karthikesalingam A, Patterson BO, Holt PJ, Thompson MM. The diagnosis and management of aortic dissection. BMJ 2011;344:d8290

25 Tolenaar JL, Hutchison SJ, Montgomery D, et al. Painless type B aortic dissection: insights from the International Registry of Acute Aortic Dissection. Aorta (Stamford) 2013;1(02): 96-101

26 Chiariello M, Indolfi C. Silent myocardial ischemia in patients with diabetes mellitus. Circulation 1996;93(12):2089-2091

27 Khafaji HAH, Suwaidi JMA. Atypical presentation of acute and chronic coronary artery disease in diabetics. World J Cardiol 2014;6(08):802-813

28 Weiner DA, Ryan TJ, Parsons L, Fischer LD, Chaitman BR, Sheffield LT Prevalence and prognostic significance of silent and symptomatic ischemia after coronary bypass surgery: a report from the Coronary Artery Surgery Study (CASS) randomized population. 22nd Bethesda Conference: Congenital heart disease after childhood: An expanding patient population 18.2 (1991):343-348. Web.

29 Li SF, Greenwald PW, Gennis P, Bijur PE, Gallagher EJ. Effect of age on acute pain perception of a standardized stimulus in the emergency department. Ann Emerg Med 2001;38(06): 644-647

30 Weintraub WS, Clements SD Jr, Crisco LV, et al. Twenty-year survival after coronary artery surgery: an institutional perspective from Emory University. Circulation 2003;107(09):1271-1277

31 Morgan CL, Currie CJ, Peters JR. Relationship between diabetes and mortality: a population study using record linkage. Diabetes Care 2000;23(08):1103-1107 